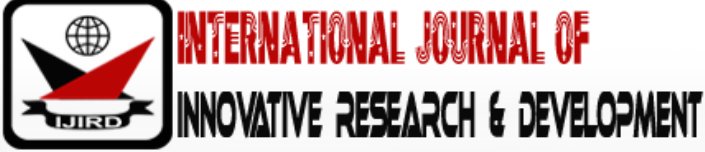

ISSN 2278 - 0211 (Online)

\section{Peaceful Co-Existence among the Religious Minorities of Bangladesh: An Analytical Study}

\author{
Lecturer (Part Time), Department of Usuluddin \& Comparative Religion, \\ International Islamic University Malaysia, Malaysia \\ Ashurov Ilkhom \\ Ph.D. Candidate, Department of Fiqh \& Usul al-Fiqh, \\ International Islamic University Malaysia, Malaysia
}

Saud Bin Mohammad

\begin{abstract}
:
Bangladesh is historically a country of many religious minorities including Hindu, Buddhist, Sheik, Animist, and Atheist. After the liberation war, it contributed immensely to sustain religious, social as well as political harmony among the people of multi religious beliefs. Despite the profound struggles from the government to sustain the harmonious living, some unavoidable incidents have taken place, such as, the assassination of number of atheists by radical Islamic group, attacking on Hindu minorities and destroying their temple, setting fire to Buddhist temples and dozens of homes, and killing of nine Christians in the church. The incidents have raised the question about the fate of religious minorities and peaceful co-existence among all religious sects in Bangladesh. This paper, therefore, attempts at examining the basic problems among all religious groups in Bangladesh that prevent the harmonious living and peaceful co-existence. At the same time, it identifies the forces that play a vital role to spread a religious fanaticism. In addition, the paper evaluates the current situation of Bangladesh in terms of social, political and religious rights of minority groups. In addressing the issue, the paper also provides some recommendations for better religious peaceful co-existence among the people of multi religious beliefs.
\end{abstract}

Keywords: Coexistence, Hindu, Buddhists, Christians, minority

\section{Introduction}

The term co-existence is applied to living with others on the basis of full respect and tolerance to their natural varieties of characteristic. There are many definitions given by different scholars from different perspectives. However, it generally indicates the following meanings; firstly, to have nonviolent relations among different thoughts; secondly, a strategy of peaceful living with other races or religions with no major dissimilarities; and thirdly, to exist together with mutual respect and tolerance. Co- existence also applies to live together accepting dissimilarities or differences in term of cultures, traditions, rituals, identities, natures avoiding all conflicts and chaos with others in order to sustain a pleasant atmosphere. Peaceful co-existence among religious minorities is a very intrinsic quality of a society where religious plurality is welcomed and diversity is accepted typically. Since the religious authority acknowledged the idea of plurality, people of different religions are appreciated. There will be no problem to have a peaceful co-existence among people of different religions as long as the authority is concern about the rights of each group and allows them to enjoy those rights. The existence of a pluralistic society could bring strength in understanding each other rather than being prejudice towards one another. If individuals are concern about their religious teachings of interrelationship, then mutual respect of people would be prevailed. It is important to note that all religions advocated people to respect each other regardless of their race, creed or color. The core message of all religions is to restoring the peace in the society, to avert and avoid all subversive activities that create restlessness among human beings. From precepts of religions it is crystal clear that no religion promotes the idea of violence, but the followers are responsible to provoke the tensions for misinterpretation of texts or for lacking precise acumen on the text. Therefore, religious text should not be blamed for the eruption of violence. It is rather the followers who are responsible for misinterpretation of the text, which creates barriers to others for religious, social and political interaction. In general, the cases of communal violence in Bangladesh are 
generally caused by religious motivation or political motive. The attacks on religious minorities continue to occur due to various reasons.

\section{Historical Background of Religious Minorities in Bangladesh}

\subsection{Christian Community}

The arrival of Christianity in Bangladesh was during the late sixteenth to early seventeenth century CE, by the Portuguese traders and missionaries who entered this country through the port of Chittagong, in the 16th century. The number of Christians in the country was not extensive as others. The domination of other religions like Hindu, Buddhist and predominantly Islam was well disseminated to many parts of the country with a number of followers and institutions, where Christianity was unfocused in the region for many years. Christianity is a minority religion in Bangladesh $(0.5 \%)^{1}$, but this number is growing rapidly.

Through the missions and activities run by few NGOs, it was observed that the Christians had hidden agendas to evangelize the underprivileged societies and to proselytize the marginalized communities. After the Bangladesh Liberation War in 1971, there was a new influx of Protestant missionary societies into Bangladesh. Besides evangelism, these societies have also established and run various educational, healthcare, and welfare institutions'2. The NGOs played a key role in a number of humanitarian projects like establishing hospitals, offering free treatments to the poor, social awareness programs, motivational campaigns, providing vocational training to the girls, micro financial activities, and establishment of free schools for poor and street children. These activities led to a prolific increase of Christians over the time.

\subsection{Buddhist Community}

Emperor Ashoka (304-232 BC), is the one who introduced Buddhism in Bangladesh. He was keenly interested to propagate Buddhism. According to Buddhist scriptures like Mahavamsa ${ }^{3}$ and Dipavamsa ${ }^{4}$ Emperor Asoka sent monks to nine places to disseminate Buddhism. This propagation was designed under the name =Dhamma Mission'led by Ven . Moggaliputta Thera. ${ }^{5}$ Two prominent monks named Ven. Sona Thera and Ven. Uttara Thera were sent under this Mission to Thailand, Myanmar and their attached area. Legendary says, on way to Myanmar the two noble The ras stayed in Bangladesh for some days and they introduced Buddhism to this land, and this is considered as a inception of Buddhism in Bangladesh. ${ }^{6}$

Buddhism continued to entrench and became dominating religion of Bengal. At the tenure of Pala dynasty it reached the final moment of boosting until the 12th century AD, the good governance of Pala dynasty and its goodwill paved the way for Buddhism to thrive in many parts of Bengal as well to reign as a dominant religion in ancient Bangle. However with the end of Pala dynasty Buddhists became to disappear gradually in the Bengal. Archeologist recovered many wreckages of Buddhist civilization naming Mohastangor, Moynamoti Buddha Bihar which carry signs that strongly vindicate the well-established existence of Buddhists civilization in Bangladesh for a long time.

Buddhism is a religion of $7 \%$ of total population of Bangladesh is followed by the indigenous people mainly living in hilly parts of the country including Mymensing, Nilfamary, Sylet and Chittagong Hill Tracts areas. The inhabitance of these ethnic minorities started even before the birth of Bangladesh.

\subsection{Hindu Community}

The history of Hinduism in the context of Bangladesh is very ancient. Many parts of ancient Bangla were reined by Hindus monarchies for a wide span of time which started to be shrunk gradually with the Muslim conquer of Indian subcontinent. Hinduism was well established in India though Indian subcontinent was ruled by Mughals for years. In 1757, after the invasion of British East India Company the state authority went to the British, who governed approximately for 200 years. For ideological reasons Muslims of Indian sub-continent were unwilling to cooperate with the colonial force, while they were welcomed by Hindus. The welcoming tendency of Hindu people to British backed them to develop themselves tremendously in all milieus of education, culture, and politics. On the other hand, Muslims were backward due to their opposition attitude towards the British colonial administration.

1.Wikipedia,the free encyclopedia. Christianity in Bangladesh. <https://en.wikipedia.org/wiki/Christianity_in_Bangladeshr> retrieved December 4, 2016 2.Christianity in Bangladesh, https://sites.google.com/site/bdguiber/home/6english/mission/christianity-in-bangladesh( retrieved December 04, 2016)

3 . Wilhelm Geiger, (ed.), Mahavamsa, Pali Text Society, London, 1980, p-26-50.

4. Bimala Churn Law, (ed.),The Dipavamsa: The Chronicle of the Island of Ceylon, Colombo: Saman Press,1959, p-164.

5 . Beni Madhab Barua, Asoka And His Inscriptions, New Age Publications , Calcutta,1968,Part - 1, p-301.

6.Suman Kanti Barua, „Present-day Buddhism in Bangladesh.\| <http://www.buddhismreligiousminorities.org/present-day-buddhism-inbangladesh/>,retrieved $11 / 27 / 16$ 
In 1947, when Indian sub-continent was divided into Pakistan and India based on separate nation state for Muslims, many Hindus who lived in East Bangle migrated to India and settled there. The number of migration was very prolific during the liberation war which affected about 90 percent of Hindu households. It is claimed that Pakistani authorities communalized the war targeting members of the Awami League and Hindus that forced most of the Hindus to flee to India. $^{7}$

However, Bangladesh previously known as East Pakistan was suffering from political and linguistic discrimination as well as economic neglect by West Pakistan led to the Bangladesh Liberation War in 1971 with a participation of people from all walks of lives irrespective of race, creed and color. This resulted the establishment of Bangladesh. As a new born state it structured its constitution on four bases of nationalism, democracy, socialism and secularism with a guaranty of security for all religious minorities. The number of Hindu people now around 17 million which makes up about $12 \%$ of the total population. In terms of population, Bangladesh has the third largest Hindu community of the world and they are the largest minority group in the country. ${ }^{8}$

\section{The Cases of Violence among the Religious Minorities}

Bangladesh is a country experiencing a peaceful co-existence among religious minorities. Since the neo Bangladesh is an output of a collective effort for many races, it took initiatives to ensure the rights of all religious groups accepting diversities to enjoy a pluralistic society certified by the constitution of Bangladesh in article 41 ; -(a) every citizen has the right to profess, practice or propagate any religion; (b) every religious community or denomination has the right to establish, maintain and manage its religious institutions $\| .^{9}$

Although human rights have been enshrined in the constitution, it was observed that the authority has not succeeded to set the rights in practice. The negligent mentality of the state authorities facilitated some radical groups or militant groups in or out side of ruling party to malpractice of social or political power which incurred huge loss to the religious minorities in Bangladesh.

Bangladesh has experienced a number of bitter incidents of violence with religious minorities which includes killing, vandalism, torture, extortion, abduction and eviction, proselytization and so on. The country started facing kind of violence every year which made many concern about the future of the religious minority of the country. Many international organizations like USCIRF were very anxious about persecution of minorities in Bangladesh. USCIRF bitterly criticized Bangladesh on November 02, 2006 for continuous persecution on minority Hindus, and urged the Bush administration to interfere and take initiatives for ensuring religious freedom and minority rights before the national elections in January $2007^{10}$.

In addition, Christians were also targeted for attack, where nine people were killed at a Roman Catholic Church in a village of southern Bangladesh known as Gopalganj District on 3 June 2001.11 Although it is expressed by many that religiously motivated violence against Christians is rare in Bangladesh. Meanwhile, Hindu minority is the most persecuted one in the context of Bangladesh; they are suffering religiously and politically since 1971. The reports of 147 attacks on Hindu religious establishments were disclosed in the social media. Moreover, house deities and shrines of Hindu people were ruined, their festivals were disrupted and properties were confiscated.12

It is claimed that religious minorities outside the Chittagong Hill Tracts have also been exiled as a result of discrimination or communal violence. The Hindu community particularly lost much of its land between 2001 and 2006 when the Bangladesh Nationalist Party was in power ${ }^{13}$. Attacking on Hindu temples and setting them into fire is not a new prototype of persecution for perpetrators. Many temples have been torched, vandalized and destroyed by the extremists in 2011, which includes Sonargaon temple in Narayanganj district of Bangladesh, where 5 people were left seriously injured during the attack. A great number of violence are broke out after the conviction of the leaders of Jamaat particularly Delwar Husain Saydee in 2013 for war crime. According to press releases of Amnesty International the violence included the looting of properties and businesses from Hindus, the burning of homes, rape and desecration and destruction of Hindu temples ${ }^{14}$. It has been vociferously chanted that, all the attacks are carried by Jamat and its student wing ISS although it bears no proof. However, community leaders opined that more than 50 Hindu temples and 1,500 Hindu homes were destroyed in 20 districts at that time ${ }^{15}$. February 21st, 2016, a senior Hindu priest Jogeshwar Roy was beheaded by militant group in the Panchagarh district of northern Bangladesh. ${ }^{16}$ Muslims ransacked 15 temples and the homes of more than 100 families as retaliation based on a posting of a derogatory image in Facebook where Hindu God Shiva was appearing on the Holly Qaba. ${ }^{17}$

7. Amena A Mohsin,. "Religion, politics and security: The case of Bangladesh." Journal of Studies, vol 8,

(1984): 485-486

8. Religion in Bangladesh,<https://en.wikipedia.org/wiki/Religion_in_Bangladesh> retrieved 12/10/16

9.The constitution of the people's republic of Bangladesh, fundamental

<http://bdlaws.minlaw.gov.bd/sections_detail.php?id=367\&sections_id=24589> retrieved 12/10/16

10. Aziz Haniffa, Bangladesh slammed for persecution of Hindus. November

02,2006<http://www.rediff.com/news/2006/nov/02aziz.htm> retrieved on 12/01/16

11."Bangladesh church bomb kills nine". BBC News. 3 June 2001.

<http://news.bbc.co.uk/2/hi/south_asia/1367073.stm> retrieved December 01, 2016. 
Buddhist community is the second most oppressed community in Bangladesh, particularly in CHT. A trail of destruction was seen at the town of Ramu in southeastern Bangladesh, which was sparked by a posted photo in Facebook insulting Islam resulted fire on Buddhist temples and homes by thousands of mob. It is reported that Sabita Chakma, a Jumma tribal women was raped and murdered by Bengali settlers. In the first three months of 2014, six more cases of rape against Jumma women have been reported against them ${ }^{18}$.

Relationship between Bengali settlers and ethnic Buddhist minority in CHT is very sensible and hostile, that made the CHT very unpredictable. Bengali settlers set fire to at least 50 houses and several shops of indigenous people and attacked including Karuna Bihar Buddhist temple in Naniarchar upazila of Rabgamati on 16 December 201419.

It can be said that all the acts of violence are originated from three main key factors, namely, religious extremism, lack of social harmony and unwelcoming mentality of cultural diversity, and finally, the negligence of authorities in implementation of minority rights.

\section{The Contributing Factors for Communal Violence}

\subsection{Religious Extremism}

Extremism is a major problem to many followers of religions and it is the result of ignorance in contextualization of text. The extremist tendency can grow up for many reasons, mostly to expose self-ideology as a best on others and cherish to dominate others, and resulted debasing others values, beliefs and ethics. It led to extremism in return, and religious extremism may hinder coexistence of races or ethnicities.

Islamic history has set up excellent examples of religious tolerance with others religions. Not only that the Muslim history is so remarkably free of the inquisitions, persecutions, witch hunts, and holocausts that tarnish history of other civilizations, it protected its minorities from persecution by others as well. It protected Jews from Christians and Eastern Christians from Roman Catholics. In Spain under the Umayyads and in Baghdad under the Abbasid Khalifahs, Christians and Jews enjoyed a freedom of religion that they did not allow each other or anyone else ${ }^{20}$.

\subsection{Lack of Social Harmony and Unwelcoming Mentality of Cultural Diversity}

It is an intrinsic quality of an ideal society that there would be religious, cultural and political harmony among all citizens regardless of race, color or language that makes a society meaningful in all sense. Focusing issues related to own culture or society paying no attention to others broadens gaps with fellow members of other cultures that lead to the lack of harmony. The gradual process of self-centering project might beget unwelcoming mentality of cultural diversity. A better coexistence can be envisioned through welcoming cultural variation in a pluralistic society which is paramount for building mutual tolerance in a side and unite them against foes on the other hand. The social issues are correlated deeply to uphold tolerance or to incept communal riots easily.

Lack of understanding other as well as incompatibility of accepting differences encourages partisan behavior in all aspects, which is an inception of silent violence that bursts into wide spectrum.

\subsection{The Negligence of Authorities in Implementation of Minority Rights}

The constitution of Bangladesh government declares that every religious community is free to work for its religion and every citizen has right to believe or practice freely. Minority issue has been addressed seriously since the independence of Bangladesh as thousands of Hindu people were killed by Pakistani army. Even after the forty five years of independence, still accusations are found against some specific groups to spread violence against minorities, but what is evident as fact behind the scene is the negligence of authority in implementation of minority rights and trace out the culprits to bring them under law and to take stern action against them. This indicates that the culprits are backed by the state authorities. Sikder Monoare Murshed says: -The most disheartening reality is that the authorities failed to provide help to the minority communities when evil forces and their student body let loose their brutal attacks. The government has expressed its intention to stop these communal attacks and punish the perpetrators. If this is a sincere promise then the government should start by implementing the recommendations given in the Judicial Commissions report submitted three years ago $\| .{ }^{21}$

12.Md. Rajib Hasnat Shakil. Systematic Persecution of Religious Minorities: Bangladesh Perspective. IOSR Journal Of Humanities And Social Science (IOSRJHSS) Volume 7, Issue 3 (Jan. - Feb. 2013). P,11

13 .Ibid,p-12

14. "Bangladesh: Wave of violent attacks against Hindu minority". Press releases. Amnesty International. 6 March 2013. <https://www.amnesty.org/en/press-releases/2013/03/bangladesh-wave-violent-attacksagainst-hindu-minority/\#.UTeKDSrYyD8.twitter> retrieved $12 / 01 / 2016$

15. Anbarasan Ethirajan, "Bangladesh minorities 'terrorised' after mob violence". BBC News. London. (9 March 2013). <http://www.bbc.com/news/world-asia-21712655> retrieved December 01, 2016

16. "Hindu priest hacked to death in Bangladesh". The Independent, 21-02-2016. <http://www.independent.co.uk/news/world/asia/jogeshwar-royhindu-priest-hacked-death-bangladeshtemple-attack-a68871

17. Julfikar Ali Manik and Ellen Barry, Hindu Temples and Homes in Bangladesh Are Attacked by Muslim Crowds Nov. 2, 2016, https://www.nytimes.com/2016/11/03/world/asia/hindu-muslim-bangladesh.html?mcubz=0> retrieved July $08,2016$. 
However, a number of reasons are responsible for promoting political violence. Prolong jurisdiction system of the country to punish the attackers is also responsible to some extent. ${ }^{22}$ Sometimes, it becomes typical to have found all unexpected incidents with minorities in the wonderful religious harmonious societies of Bangladesh. The key factor behind all nasty activities is the blaming character of political parties to their oppositions for every unpleasant situation in the country just for political gain, rather than taking actions promptly, which saves the real criminals from judicial punishment.

Monoare Murshed goes on saying: - Not only that after each of this attack, two main political parties Awami League and BNP start to blame each other and ultimately try to shelter their activists involved with violence. This sort of political indemnity is a big reason why incidences of communal attacks are repeated in Bangladesh. And for this kind of political immunity, the acts and sections of Bangladesh Penal Code fails to protect the rights of the oppressed. $\|^{23}$

In fact, this kind of political immunity became a political tradition for the parties to save churoots from any sort of litigation which is mostly responsible for raise of more violence and restlessness.

\section{The Initiatives for Peaceful Co-Existence}

The issues related to minorities in Bangladesh concern of many national and international organizations. The current government of Bangladesh run by Awami League inserted secularism as a basic principle of state (which was obliterated by President Major Ziaur Rahman in 1977) ${ }^{24}$ to ensure the rights of all religious sects and denominations. At the same time, Bangladesh government has taken multi-pronged initiatives to restore the peaceful co-existence among all races in the country. As came to the report, that President Abdul Hamid has taken initiative to enhance peace and harmony among religious minorities, and funds were given to Islamic Foundation, the Hindu Welfare Trust, the Christian Religious Welfare Trust, and the Buddhist Welfare Trust by the Ministry of Religious Affairs to run various activities including literacy and religious programs, festivals, religious building repair, and so on. ${ }^{25}$

National and international organizations are working for the development of ethnic minorities focusing particularly in the hilly areas of Chittagong Hill tracts. Local NGOs are working for the development of CHT minorities in various ways. Since Bangali language is a challenge for the kids of ethnic minority to catch up the idea to understand, NGOs came forward to assist them to have the education in the early stage in their mother tongue. It was reported that,_a few NGOs have launched an initiative to teach Chakma, Marma and Tripura children in their respective languages at the preschool stage in a few schools in and outside the municipality area. ${ }^{26}$

Human rights organizations all over the world expressed their concern to the government of Bangladesh to take action to uphold minority rights. Many human rights NGOs came forward to provide legal assistance to the persecuted and marginalized ethnic minority. Human Rights Congress for Bangladesh Minorities (HRCBM-Dhaka) is one of those working to promote human rights in Bangladesh, to stop human rights violations against Bangladesh minorities by creating worldwide awareness against such violations, helping victims by providing shelter, rehabilitation and other forms of humanitarian assistance. ${ }^{27}$

Bangladesh government enacted Chittagong Hill Tracts Land Dispute Settlement Commission Act $2001^{28}$ to settle land disputes existing for years and recover the grabbed by Bengali settlers in hill tracts. According to the State Department's 2014 IRF Report, the Bangladeshi government's failure to adequately respond to incidents of social persecution has accentuated the problems that minorities face in the country. ${ }^{29}$

\section{Basic Tenets of Peaceful Co-Existence and Religious Tolerance}

- To love and care others.

- To live with unity within diversity.

- Maintain good neighborliness.

- To encourage and strive for peaceful living.

- To respect others' beliefs, feelingsand acknowledge their religion.

- To ensure justice, equality where it is needed.

- Development of mutual understanding.

- Working for collective development.

- Continuation of interfaith dialogue.

- Saying "No"to all kinds of violence and inhuman behavior.

- Accepting others with differences. ${ }^{30}$

18. "Chittagong Hill Tracts of Bangladesh - rapists act with impunity" (3 April

2014).<http://www.survivalinternational.org/news/10141> retrieved December 01.2016

19. "Chittagong Hill Tracts: Town of Chakma Villagers Attacked and Houses Burned Down". Unrepresented Nations and Peoples Organization.December18,2014.<http://unpo.org/article/17798> retrieved December 01,2016

20.Khalid Baig ,On Religious Tolerance ,25 Zul-Hijjah 1421, 21 March $2001<$ http://www.albalagh.net/food_for_thought/tolerance.shtml >retrieved December 7, 2016.

21. Sikder Monoare Murshed, Democracy and Minority Rights in Bangladesh, http://alfpnetwork.net/wpcontent/uploads/2016/02/ALFP2014Report_Sikder-M.-Murshed.pdf, (n.p, n.d,), retrived August 25,2017 p,6 


\section{Conclusion}

Co-existent is an idea championed by all religions of the earth directly or indirectly, explicitly or implicitly, literally or metaphorically. There is no single religion which advocates the idea of violence. It is not a symbol of the real character of religion although a number of annoying incidents happen by the followers of a specific ideology or religion. Religious lessons are blessings to the mankind when these are followed in balanced way. Religious scholars are responsible greatly for contextualization of the texts to restore peace in the real sense. They should disseminate the importance of maintaining peaceful coexistence through developing the concept of mutual tolerance and accepting diversities from religious aspects. Meanwhile, state authorities through legal aspects should apply a proper implementation of minority rights and most importantly sentencing the criminals accused for attacks and violation of minority rights. The following points are few recommendations for a peaceful co-existence among the religious minorities in Bangladesh;

- Religious authorities should be more concern in terms of translation of religious text so that the exegesis contributes in building the unity among the followers of all religion rather than destroy.

- Reformation of minds is utterly important to avoid extremism and fundamentalism from religious perspective.

- Inclusion of religious teachings of tolerance, sympathy, compassion, peace and coexistence in education curriculum, so that the nation grows with these values and ethics.

- The majority Muslims should open the ground for non-Muslims to cherish their beliefs and observe their occasions freely.

- Followers of every religion should have respect to others values, ethos, ethics, beliefs and religion.

- Religious leaders could gather yearly or half yearly and discuss the methods to promote tolerance among the followers.

- Government should be more cordial about minority rights and to implement those perfectly without discrimination.

- Security of life and property of the minority communities should be guaranteed in Bangladesh.

- More effective plans should be made by the state authority to create scopes for ethnic minorities in terms of education and jobs to improve their life standard.

- Perpetrators involved in communal violence like killing minority people, vandalizing their homes and temples should be brought under the law and sentence exemplary punishment.

- Preventing inequity against religious minorities in all levels of government and non-government jobs, including the armed military and Para military department.

- Protect basic human rights as enshrined in the constitution and open doors NGOs and Human Rights organizations to work freely for marginalized community.

\section{References}

i. Ahmad, Tariq.Report for the US Department of Justice, LL File No. 2016-013914, Bangladesh: Treatment of Religious Minorities, The Law Library of Congress, Global Legal Research Center, (August 2016).

ii. Barua, Beni Madhab. Asoka and His Inscriptions, New Age Publications, Calcutta. (1968).

iii. Bangladesh Jatiya Sangsad, Bangladesh Gazette ,The People's Republic of

iv. Bangladesh, Extraordinary Published by Authority, Dhaka, July 17, 2001/ Shraban 2, 1408.

v. Barua, Suman Kanti.-Present-day Buddhism in

Bangladesh $\| .<\mathrm{http}: / /$ www.buddhismreligiousminorities.org/present-day-buddhism-in-bangladesh/>,retrieved $11 / 27 / 16$

vi. Biswas, Biva Rani. Intervention Under Item 3(a) of the Provisional Agenda: Violation of Linguistic and Cultural Rights of Minorities of Bangladesh,

vii. Commission on Human Rights,Sub-Commission on the Promotion and Protection

viii. of Human Rights, $11^{\text {th }}$ Sessions of Working Group on Minorities,30 $3{ }^{\text {th }}$ May to $3^{\text {rd }} J u n e, 2005$.

ix. Baig, Khalid. On Religious Tolerance ,25 Zul-Hijjah 1421, 21 March 2001 <http://www.albalagh.net/food_for_thought/tolerance.shtml >retrieved December 7, 2016

x. Dewan ,Tuli. Bangladeshi NGOs address education gap for minorities, Common

xi. Ground News Service, 19August, 2008<http://www.commongroundnews.org/article.php?id=23778\&lan=en\&sid=1 \&sp=1\&isNew=0> retrieved December 07,2016.

xii. Ethirajan, Anbarasan. "Bangladesh minorities 'terrorised' after mob violence". BBC News. London. (9 March 2013). <http://www.bbc.com/news/world-asia-21712655> retrieved December 01, 2016.

xiii. Haniffa, Aziz. Bangladesh slammed for persecution of Hindus. November 02, 2006<http://www.rediff.com/news/2006/nov/02aziz.htm> retrieved on 12/01/16

xiv. Lintner, Bertil. ||Religious extremism and nationalism in Bangladesh." The Bangladesh Observer (2002).

xv. Mohsin, Amena A. "Religion, politics and security: The case of Bangladesh." Journal of Studies, vol 8, (1984) 
xvi. Murshed, Sikder Monoare. Democracy and Minority Rights in Bangladesh, http://alfpnetwork.net/wpcontent/uploads/2016/02/ALFP2014Report_Sikder-M.-Murshed.pdf, (n.p, n.d,), retrived August 25,(2017).

xvii. Manik, Julfikar Ali and Barry, Ellen. Hindu Temples and Homes in Bangladesh

xviii. Are Attacked by Muslim Crowds, Nov.2, $2016,<$ http://www.nytimes.com/2016/11/03/world/asia/hindumuslim-bangladesh.html?_r=0> retrieve July 08, 2016

xix. Law, Bimala Churn. (ed.),The Dipavamsa: The Chronicle of the Island of Ceylon,(Colombo: Saman Press,1959).

22. Ibid.p,7

23. Ibid, $\mathrm{p}, 6-7$

24. Bertil Lintner,. "Religious extremism and nationalism in Bangladesh." The Bangladesh Observer (2002).

25. Tariq Ahmad, Report for the US Department of Justice, LL File No. 2016-013914, Bangladesh: Treatment of Religious Minorities, The Law Library of Congress, Global Legal Research Center, (August 2016): 11.

26. Tuli Dewan ,Bangladeshi NGOs address education gap for minorities, Common Ground News Service, 19August,2008<http://www.commongroundnews.org/article.php?id=23778\&lan=en\&sid=1\&sp=1\&isNew $=0>$ retrieved December 07,2016

27. Biva Rani Biswas, Intervention Under Item 3(a) of the Provisional Agenda: Violation of Linguistic and Cultural Rights of Minorities of Bangladesh, Commission on Human Rights,Sub-Commission on the Promotion and Protection of Human Rights, $11^{\text {th }}$ Sessions of Working Group on Minorities,30th May to $3^{\text {rdjune, } 2005}$

28. Bangladesh Jatiya Sangsad, Bangladesh Gazette ,The People‘s Republic of Bangladesh, Extraordinary Published by Authority, Dhaka, July 17, 2001/ Shraban 2, 1408.

29.Tariq Ahmad, Report for the US Department of Justice, p4.

30 . Hanna Onyi Yusuf, Promoting Peaceful Co-Existence and Religious Tolerance through Supplementary

Readers and Reading Comprehension Passages in Basic Education Curriculum, Vol. 3, No. 8, (Special Issue - April 2013 ):226 